\title{
Development of Mathematics and Science Teacher Competencies through Coaching
}

\author{
Gantanat Chalong, Malai Tawisook, Thanin Ratanaolarn \\ King Mongkut's Institute of Technology Ladkrabang, Bangkok, Thailand \\ Email: 54630152@kmitl.ac.th
}

How to cite this paper: Chalong, G., Tawisook, M., \& Ratanaolarn, T. (2017). Development of Mathematics and Science Teacher Competencies through Coaching. Creative Education, 8, 2049-2063. https://doi.org/10.4236/ce.2017.813139

Received: May 11, 2017

Accepted: October 16, 2017

Published: October 19, 2017

Copyright $\odot 2017$ by authors and Scientific Research Publishing Inc. This work is licensed under the Creative Commons Attribution International License (CC BY 4.0).

http://creativecommons.org/licenses/by/4.0/

\section{(c) (i) Open Access}

\begin{abstract}
Faced with impacts from globalization, rapid technological advancement and increasing competition, educational systems worldwide are racing to find sustainable ways to improve student achievement. As teachers are a direct conduit to students and their performance, targeting the development of teacher competency is an avenue worth exploring. An attractive option toward improving educational standards and achievement is coaching, as it is ongoing support for teachers. The objective of this study was to analyze existing literature on coaching in order to develop and implement a coaching system to facilitate professional development and increase instructional competencies of primary school math and science teachers at a private primary school in Samutprakan, Thailand. Data was gathered through interviews and questionnaires conducted with coaches, teachers and students, with results indicating a high degree of satisfaction, most notably in teachers, with coaching allowing them to discover alternate possibilities and bolstering their skills and efficacy.
\end{abstract}

\section{Keywords}

Coaching, Professional Development, Student Achievement, Sustainable Education, Teacher Competency

\section{Introduction}

Countries with successful school systems recognize the crucial role teachers play in student achievement and have policies to foster the proper recruitment, training and development of teachers to give their students access to instruction that is both equitable and of high caliber (Darling-Hammond, Chung-Wei, \& Andree, 2010). While academic content is evolving to keep pace with a rapidly changing world, educational systems have been experimenting with countless strategies of innovation and reform. However, it is not curricula, but the quality 
of teachers that is key to students' success (Birman, Desimone, Porter, \& Garet, 2000) and much attention must be paid towards the goal of instituting sustainable processes to maintain teaching standards.

Efforts to strengthen a failing educational system have been constant throughout Thailand's recent history, with the Thai government year after year investing a considerable portion of its annual national budget, relative to allocations made in comparable countries, into education (Corcoran, 2015). This financial investment, sadly, has yet to bear any fruit in the form of improved academic achievement.

Despite great progress being made by students from neighboring countries such as Singapore, Thai students consistently score poorly on both domestic and international assessments. Thai teachers are the product of an antiquated, top-down educational system rife with rote instruction and inadequate training, and the country needs to properly train and develop its teachers to evolve and abandon ineffectual practices and habits in order to engage their students and motivate them toward an acceptable level of academic achievement (Thailand Development Research Institute, 2012).

The competencies of available teachers are dictated not just by their formal training but also by work experience. Professional development is a valuable tool that allows for schools to strengthen the teachers they have in hand. In his seminal study, Harold Wenglingsky (2000) determined that professional development was a pivotal factor towards enhancing students' learning outcomes. Coaching, out of the various types of professional development studied, proved to be most effective; students whose teachers received coaching outperformed those whose teachers did not. It is important to note not just teachers' efficiency, however, but also their efficacy, that is, what they are capable of, as well as their belief in such. Professional development can bolster teachers' awareness and confidence in what is possible, in turn encouraging a thirst for improvement and the desire for higher standards (Yoo, 2016).

Because it is a continuous, ongoing process that sees to personal improvement, coaching differs from traditional professional development methods such as workshops or seminars, which are largely limited, off-site and one-time-only training activities conducted by strangers that teachers may never meet again. Coaching is conducted at the actual location where the teachers being coached, called "coaches", teach, and with a colleague from whom they can receive ongoing feedback (Russo, 2004). This increases the likelihood of skills transfer, meaning that coachees will be better able to transfer the skills newly acquired from coaching for implementation in their classrooms (Chien, 2013), although precedent exists where online instruction was utilized as a professional development component (Yoo, 2016). That numerous workshops and seminars, one-shot "events" so common to the teaching profession, have had little impact reflects that it is a misconception that nuggets of skills and knowledge can be learned off-site in one sitting and then taken back and implemented in a completely different environment (Showers \& Joyce, 1996). 
It must be noted that coaching is not mentoring. While both have similar characteristics that lead to a misunderstanding that they are interchangeable, coaching and mentoring are distinctly different processes in several key aspects. Coaching and mentoring both involve a more expert party guiding a less experienced one, but coaching's focus is more specific and targets particular areas of need in order to improve skills, performance and outcomes within a specified time. Coaching is a structured process of targeted development while mentoring, on the other hand, is akin to an ongoing apprenticeship (Lord, Atkinson, \& Mitchell, 2008).

With Thai teachers needing to change viewpoints and adopt new tactics, schools can look to coaching to develop teachers' instructional competencies to transform them into effective professionals. By helping teachers become better at their craft, schools will have a sustainable way to improve educational outcomes and overall institutional quality. In dire need of overhauling its educational system to become competitive on the world stage, Thailand needs to determine ways to successfully implement coaching systems within its schools to meet this end.

\section{Objectives}

This study aimed to address deficiencies in teacher performance by developing and implementing, within the constraints of a typical Thai primary school, a coaching system to develop and improve instructional competencies of primary school teachers, and thus student achievement, in the subjects of mathematics and science using principles and information gathered from existing research and literature on the practice of coaching as it applies to teachers and education.

As illustrated in Figure 1, the conceptual framework for the research involves first the study of the practices of teachers in the subjects of mathematics and science to examine the conditions of their teaching and ascertain problems that exist. From research into coaching, a template for development of a coaching system is subsequently devised, with the aim being improved competencies on the part of coached teachers in specific areas of practice.

\section{Methodology}

The research conducted a review of literature pertaining to coaching and the coaching process and used the information gathered as parameters to fashion a coaching system. This system was then implemented at a private primary school in Samutprakan, Thailand, named Bangpleepattanasuksalai School, which has a student population of approximately 1000 students from kindergarten to lower secondary levels.

The subjects of mathematics and science were chosen for the study because they require deduction, and mathematics and science teachers' effectiveness beyond rote instruction can be assessed by their level of success in the cultivation of students' critical and creative thinking in respect to these relatively abstract subjects. With primary six being a year wherein students already have many 


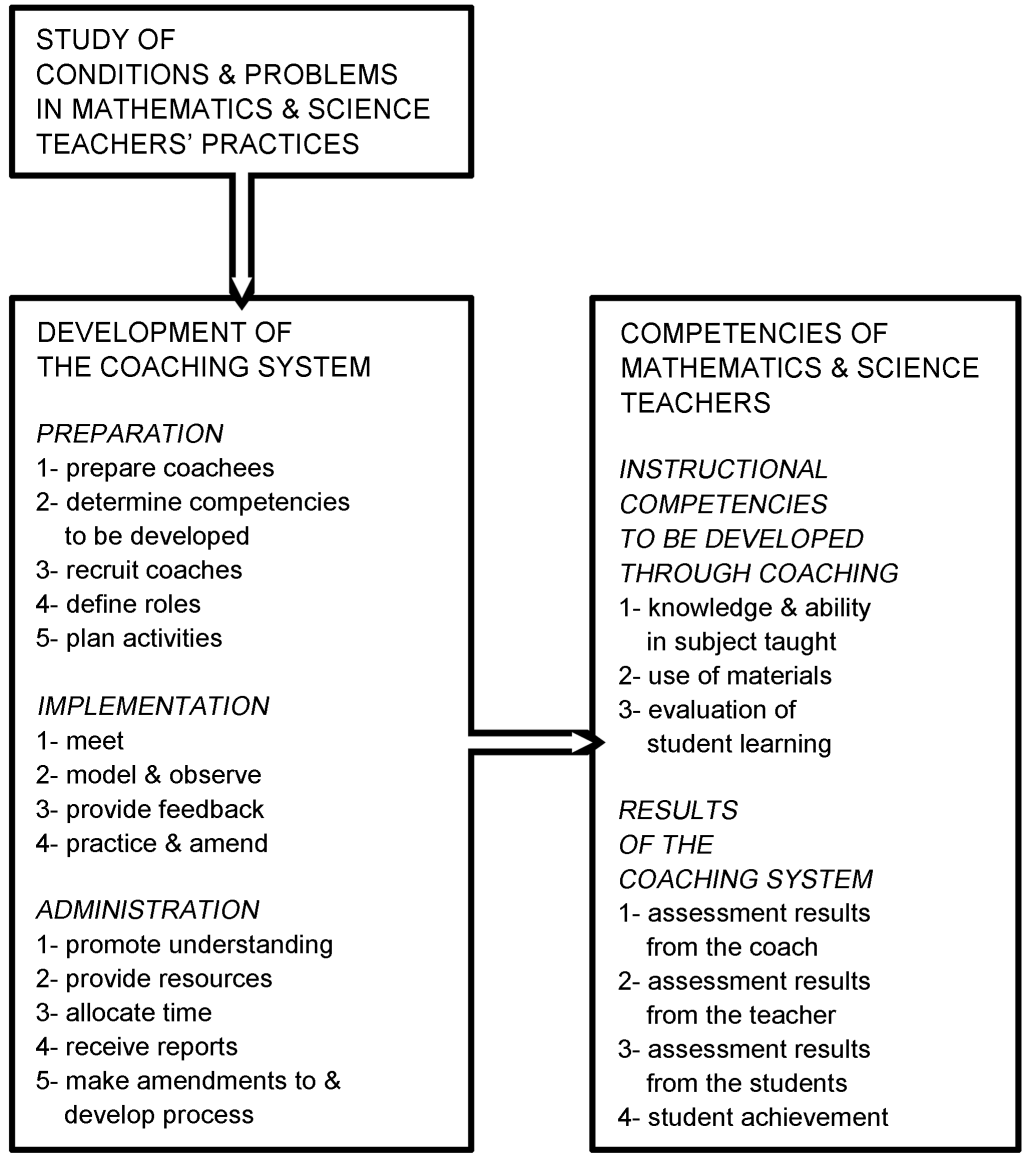

Figure 1. Conceptual framework.

evaluative activities available, teachers from this level were chosen to be the coachees. One mathematics coach was assigned to the school's single primary six mathematics teacher and one science coach was assigned to the school's single primary six science teacher.

The coaching process was executed over a period of twenty weeks, equal to one academic term in Thailand, beginning with an initial classroom visit from the coaches and continuing with face-to-face conferences between coaches and coachees every other Saturday in addition to periodic video demonstrations by both the coaches and the coachees.

Interviews, open-ended questionnaires for coaches and coachees, and Likert scale questionnaires for students, all with questions vetted by experts in related fields of management and education, were utilized for data collection and analysis regarding participant feedback and satisfaction.

\section{Literature Review}

There exist many types of coaching. For the purposes of this study, the term "coaching" refers to instructional coaching, which is the conventional process wherein expert coaches help coachees improve in specific areas of need. Assessments need to be made at an initial stage as to coachees' receptiveness to partic- 
ipation and their knowledge and skill level. The institution must also have the means and ability to effectively support the coaching system. Determining which type of coaching to utilize is important as each has different requirements and considerations (Cornett \& Knight, 2009). Yet there are traits common to all types of coaching, as the process aims to develop specific aspects of professional practice. Coaching is a continuous process, similar to mentoring, but it differs in its structure and schedule, developing particular skills within set timeframes (Knight, 2009). Elements of coaching include the recruitment, and training if necessary, of coaches, pairing of coaches and coachees, practice, application and regular observations (Moffet, 1987).

Also important is the relationship between quality and quantity. The breadth, or scope, of the coaching must not adversely impact the quality of the experience and the ratio of coachees to coach is a factor to be considered. Effective coaches should have extensive expertise in classroom instruction and collaborative experience with other educators. They should be open-minded, trustworthy and adept at observation, modeling, and providing meaningful feedback without judgment (Chien, 2013). Furthermore, pairing coaches with coachees who share common levels or subject matter taught is preferable (Birman, Desimone, Porter, \& Garet, 2000). Even though one party is considered expert and the other novice, coaches and coachees should see each other as equals, as the focus of the instruction is in fact dictated by the needs of the coachee, not the coach, and it is essential that coachees have input into the direction of the coaching in addition to the choice of whether or not to participate (Robbins, 1991).

Institutions and administrators are responsible for allowances of time and support as needed by the coaching system (Lord, Atkinson, \& Mitchell, 2008). Administrators need to promote support for the coaching system from all stakeholders by demonstrating recognition of its value. By dedicating attention, resources and time to the process, administrators convey the idea that coaching is a process the institution is taking seriously (Garmston, 1987) and positively influence teachers' perception of the coaching system, thereby nurturing a culture within the school that is conducive to learning not just for students but for staff as well. It is also essential that administrators see to it that teachers regard being coached not as a punishment or sanction, but a system of support (Knight, 2009). In effect, this sustainable leadership is the glue that holds together the entire organization and the leader's commitment in turn elicits the commitment of other stakeholders. For teachers, this commitment is a direct link to retention and therefore supports continuity in a school's processes. Sustainable leadership bolsters commitment by empowering human resources and provides for the shared values and beliefs within an organization. A sustainable leader creates conditions that support the wholeness of an organization and recognizes that education exists not just for learning knowledge but also for learning how to live and function together with others (Cherkowski, 2012).

As a professional and on-the-job resource, coaching also has potential to be a benefit to teacher induction, as novice teachers face stress and workload exacer- 
bated by inexperience, unfamiliarity and low-efficacy. Mentoring is a common support system available to new teachers (Geng, Midford, \& Buckworth, 2015), and utilizing coaching as an additional means to acclimate novice teachers to their new profession is an avenue worth exploring.

Coaching deals with cultivating behavior, developing content knowledge, providing direct instruction, and making formative assessments (Knight, 2007) and its effect on teacher efficacy makes students see their teacher in a new light. In one study, after an extended period of coaching involving class observations, self-assessments and reflective interviews, the coachee gained a willingness to try new ideas and his newfound mastery of the content and increased confidence resulted in higher student opinions in regard to their teacher (Bruce \& Ross, 2008). Coachees must be open to letting themselves undergo a transformative process, and aware that to inspire change in students they must first be willing to change themselves. With open minds, coachees can play their part in effecting societal change through example and lead future generations to make positive impacts in a sustainable manner (Iliško, 2007).

Cantrell \& Hughes (2008), in another study, concluded that ongoing support was an essential attribute of coaching. Surveys taken before and after the process showed that coachees saw the benefit of continuous training. In coaching, after professional development is designed and delivered, the coach is still available to coachees to help plan lessons, to model, observe and provide further resources as necessary (Chien, 2013). In this ongoing cycle of observation and feedback, new skills are continually determined to be enhanced, coaches demonstrate them, the coachee practices them; feedback is provided to one another and then the whole process begins anew, with future experimentation and study, not evaluation, being the aim (Showers, 1985). This process of practice and feedback takes time, as coaches and coachees figure out together how best to apply new approaches and techniques, and then to gradually utilize them in everyday routines until they become familiar and habitual. To expect instantaneous results is simply unrealistic. The coaching of athletes, which is perhaps the most widely understood application of coaching, is a great reminder that proficiency comes with much time and effort (Joyce \& Showers, 1982). This is in fact often cited as an advantage coaching has over other modes of professional development, as the cycle of trial, error and follow-up is necessary for teachers to not only adopt new skills but to change their behaviors overall (Lieberman, 1995). Being an ongoing process and an instrument for not only personal but societal change is clear indication that coaching addresses larger issues of sustainable education, as sustainability itself is a continually progressive undertaking that requires change in how one thinks and how one identifies and addresses problems. Coaching, like sustainability, involves envisioning, acting and reviewing, and is a process of reflection instead of simple personal advancement that is driven by the learner through means of identifying root causes of problems and acting on them in an inclusive manner (Tilbury, 2007). As such, greater social change starts with the development of teachers' practices and approaches as teachers themselves act as immediate role 
models for the future generations they are shaping.

A clear template can be envisioned from the literature and case studies surveyed, as there are many common traits and aims in existing foreign examples of coaching for teachers. However, its application to teaching practices and educational norms in Thailand is yet relatively untested, certainly on any large scale.

\section{Design of the Coaching System}

Analysis of pertinent research and related literature found significant commonalities in different examples of coaching. In terms of structure, coaching systems for the most part are comprised of three basic segments: preparation, implementation and administration (Figure 2).

The preparation segment, wherein the focus, participants, activities, schedules, goals and other parameters of the coaching process are basically set, would need to be accomplished before formal coaching can begin. This formal coaching period, contained within the implementation segment, refers to the execution of the coaching process itself, encompassing coach and coachee interactions, modeling, observation, feedback and the following adjustments made to practice. The third segment, administration, does not exist linearly with the other two segments but rather concurrently and accounts for the responsibility of management to provide for, oversee and support the factors necessary for the successful acceptance, integration and operation of the coaching system as a whole, including promotion of awareness about the benefits of coaching, provision of time and physical resources and amending the process as necessary.

Preparation for coaching began with the education of stakeholders, specifically the coachees who needed to be apprised of the specifics of the coaching process, its aims, requirements and expectations. For Bangpleepattanasuksalai

\begin{tabular}{|c|c|}
\hline $\begin{array}{l}\text { segment: } \\
\text { PREPARATION }\end{array}$ & $\begin{array}{l}\text { components: } \\
\text { 1- prepare coachees } \\
\text { 2- determine competencies to be developed } \\
\text { 3- recruit coaches } \\
\text { 4- define roles } \\
\text { 5- plan activities }\end{array}$ \\
\hline $\begin{array}{l}\text { segment: } \\
\text { IMPLEMENTATION }\end{array}$ & $\begin{array}{l}\text { components: } \\
\text { 1- meet } \\
\text { 2- model \& observe } \\
\text { 3- provide feedback } \\
\text { 4- practice \& amend }\end{array}$ \\
\hline $\begin{array}{l}\text { segment: } \\
\text { ADMINISTRATION }\end{array}$ & $\begin{array}{l}\text { components: } \\
\text { 1- promote understanding } \\
\text { 2- provide resources } \\
\text { 3- allocate time } \\
\text { 4- receive reports } \\
\text { 5- make amendments to \& develop process }\end{array}$ \\
\hline
\end{tabular}

Figure 2. Segments and components of the coaching system. 
School, coachee selection was not an issue as the school had only one sixth grade mathematics teacher and one sixth grade science teacher. Being the main actor in the administration segment, the principal was responsible for briefing the coachees about coaching, their roles and the intended goals and expectations of the coaching process. After bringing both coachees on board, the instructional competencies which they needed to develop were identified. After a focus group was held with the coachees, school management, and academic supervisors, it was determined that the areas the coachees most needed to enhance involved content, instructional materials and student evaluation.

With coachees in place and developmental need identified, the next step in the preparation segment would be the recruitment of the coaches. The search for coaches was met with difficulty because, since coaching for teachers is a relatively novel practice in Thai education, the pool for adequate coaches is limited. Eventually, two coaches were found, one with extensive experience teaching mathematics and the other science. The limited number of choices, however, made it necessary for concessions to be made in light of both coaches' work commitments and it became apparent that their physical availability to be on-site was limited, so scheduling was now an issue. The preparation segment was completed with the coaches meeting with the principal to plan the coaching process, clarify their roles and determine a schedule for the topics to be taught over the twenty-week duration of the study.

The implementation segment of the coaching system at Bangpleepattanasuksalai School began as the formal coaching period commenced. The coaches were introduced to the coachees and each party disclosed their backgrounds, achievements, and thoughts. This was followed by an initial classroom visit, wherein each coach observed each coachee's performance in her actual occupational setting. Feedback based on the observations was given by the coaches and further discussion was had to establish how to move forward. Because the coaches were not available to visit the coachees' classes during the weekdays, it was agreed that both coachees would provide the coaches with regular video recordings, which would be used in lieu of in-person classroom visits to allow the coaches to observe them in practice. In turn, the coaches would also provide the coachees with recordings of modeling as instructional reference and feedback. Despite these constraints, face to face consultation was still deemed necessary, and the principal arranged for on-site meetings between the coaches and coachees every other Saturday.

The principal was involved concurrently throughout this entire process as part of the administration segment, being responsible for overseeing management of the coaching system. This meant facilitating the process by ensuring that necessary resources such as materials, equipment and finances were available and enough time was allocated for the coaching process to be executed properly. Assessment conducted by management is of the system, not the individuals within it, and involved quality assurance by way of maintaining focus and continuity. Management gave support as needed and took care to avoid inappropriate and 
unnecessary interference into the activities of the coach and coachee. It fell on the principal's shoulders to be the most vocal cheerleader for the coaching system, recognizing and rewarding participants for progress as well as crediting the process for improvements in instruction and achievement.

\section{Results}

Both coachees regarded the coaching process and system positively and believed that their respective coaches helped improve their skills and pointed out new perspectives for them to explore.

Communication skill is one area where the mathematics coachee found her coach especially helpful. While it was valuable that the mathematics coach was knowledgeable in content and imparted guidance on teaching the subject matter, the mathematics coachee found that without being able to communicate that content to her students clearly and accurately, the content itself was of little value. Her coach made her aware of her previously inappropriate or even inaccurate vocabulary choices and taught proper language to use while teaching. The science coachee's presentation skills were also improved, with her coach encouraging her to better engage her students by being more creative in her approach. She also noted that the science coach helped her formulate better questions to make students think, and to provide enough time for them to formulate their own answers. Before, she lacked patience and simply provided the answers herself should there be a pause. Beyond just knowing content, the coachees felt they benefitted greatly from learning how to communicate ideas and interest their students. This competency in communication is just one gap resulting from inadequate teacher education and is a problem not unique to Thailand (Gallego, Ortega, \& Fuentes, 2015), but specific deficiencies beyond this can be targeted and addressed through coaching as well.

In the use of materials, the coaches pointed out to both coachees alternate possibilities and encouraged utilization of already available materials, which also helped the institution avoid unnecessary waste. Introducing multiple boards throughout the classroom for students to prepare written answers to present also eliminated much wasted time from students writing answers on the main board one at a time.

Both coachees also indicated that the coaching increased their efficacy, especially in terms of measurement and evaluation of students' comprehension, since they had been unfamiliar with standard assessments for primary six, particularly the Thai national standardized tests given annually to primary 6 students. They learned from their coaches about which indicators to focus on, and how to fashion assessments to more accurately and appropriately evaluate knowledge and skills which were relevant to student achievement.

The coachees' improved performance in these areas was reflected in student satisfaction and achievement.

Based on feedback from student questionnaires, both coachees received high levels of satisfaction from their students, as shown in Table 1 and Table 2. 
Table 1. The mean standard deviation of student satisfaction of mathematics teacher performance.

\begin{tabular}{|c|c|c|c|c|c|}
\hline \multicolumn{3}{|c|}{ Competency by instructional area (Mathematics teacher) } & \multirow{2}{*}{$\frac{\bar{x}}{4.33}$} & \multirow{2}{*}{$\begin{array}{c}\text { Standard deviation (S.D.) } \\
\mathbf{0 . 7 1}\end{array}$} & \multirow{2}{*}{$\frac{\text { Degree of satisfaction }}{\text { High }}$} \\
\hline Ins & uctional area 1: Knowledge and ability in subject & Combined average: & & & \\
\hline 1.1 & \multicolumn{2}{|c|}{ Introduces content to stimulate student interest } & 4.20 & 0.71 & High \\
\hline 1.2 & \multicolumn{2}{|l|}{ Is knowledgeable in content } & 4.50 & 0.55 & Highest \\
\hline 1.3 & \multicolumn{2}{|c|}{ Teaches content at appropriate level for students } & 4.38 & 0.63 & High \\
\hline 1.4 & \multicolumn{2}{|c|}{ Has clarity in teaching and explicit objectives } & 4.26 & 0.79 & High \\
\hline 1.5 & \multicolumn{2}{|c|}{ Has teaching activities that motivate self-learning } & 4.52 & 0.74 & Highest \\
\hline 1.6 & \multicolumn{2}{|c|}{ Provides various learning activities } & 4.21 & 0.84 & High \\
\hline 1.7 & \multicolumn{2}{|c|}{ Utilizes engaging teaching methods } & 4.40 & 0.70 & High \\
\hline 1.8 & \multicolumn{2}{|c|}{ Transfers knowledge and facilitates student understanding } & 4.40 & 0.79 & High \\
\hline 1.9 & \multicolumn{2}{|c|}{ Motivates and supports students to reach full potential } & 4.28 & 0.63 & High \\
\hline 1.10 & \multicolumn{2}{|c|}{ Creates and maintains environment conducive to learning } & 4.26 & 0.73 & High \\
\hline 1.11 & \multicolumn{2}{|c|}{ Summarizes content with clear conclusion at end of each lesson } & 4.23 & 0.69 & Highest \\
\hline & Instructional area 2: Use of materials & Combined average: & 4.34 & 0.73 & High \\
\hline 2.1 & \multicolumn{2}{|c|}{ Uses materials and supplements to support teaching } & 4.45 & 0.70 & High \\
\hline 2.2 & \multicolumn{2}{|c|}{ Uses materials and supplements that encourage and facilitate learning } & 4.28 & 0.77 & High \\
\hline 2.3 & \multicolumn{2}{|c|}{ Has materials consistent with content } & 4.38 & 0.66 & High \\
\hline 2.4 & \multicolumn{2}{|c|}{ Makes use of supplemental documents and resources beyond class materials } & 4.26 & 0.79 & High \\
\hline & Instructional area 3: Evaluation & Combined average: & 4.36 & 0.77 & High \\
\hline 3.1 & Has tools and methods of evaluation & Combined average: & 4.43 & 0.67 & High \\
\hline 3.1 .1 & \multicolumn{2}{|l|}{ Hands-on experience/lab } & 4.24 & 0.91 & High \\
\hline 3.1 .2 & \multicolumn{2}{|l|}{ Worksheets and written exercises } & 4.60 & 0.48 & Highest \\
\hline 3.1 .3 & \multicolumn{2}{|l|}{ Examinations } & 4.44 & 0.63 & High \\
\hline 3.2 & Measures achievement by unit studied & Combined average: & 4.37 & 0.50 & High \\
\hline 3.2 .1 & \multicolumn{2}{|l|}{ Learning unit 1: whole numbers } & 4.24 & 0.63 & High \\
\hline 3.2 .2 & \multicolumn{2}{|l|}{ Learning unit 2: equations } & 4.32 & 0.44 & High \\
\hline 3.2 .3 & \multicolumn{2}{|l|}{ Learning unit 3: factors } & 4.28 & 0.46 & High \\
\hline 3.2 .4 & \multicolumn{2}{|l|}{ Learning unit $4:$ lines $\&$ angles } & 4.48 & 0.67 & High \\
\hline 3.2 .5 & \multicolumn{2}{|c|}{ Learning unit 5: directions \& diagrams } & 4.72 & 0.40 & Highest \\
\hline 3.2 .6 & \multicolumn{2}{|l|}{ Learning unit 6: fractions } & 4.16 & 0.40 & High \\
\hline 3.3 & \multicolumn{2}{|c|}{ Openly discloses results from evaluations } & 4.30 & 0.86 & High \\
\hline 3.4 & \multicolumn{2}{|c|}{ Provides feedback to allow for self-improvement } & 4.42 & 0.88 & High \\
\hline 3.5 & Evaluates transparently, clearly anc & & 4.28 & 0.93 & High \\
\hline
\end{tabular}

Students felt they now better understood the material they were taught and were more active participants in their own education. Their teachers' new approach to instruction engaged students' interest, reflected in high levels of student achievement as well.

In terms of student achievement, students scored well above targeted goals in the units taught during the coaching process. Results from school examinations, illustrated in Table 3 and Table 4 for mathematics and science respectively, 
were well above targeted scores in the units taught during the coaching period of one academic term. Furthermore, overall student achievement as determined by internal school evaluations for the total academic year also reflected performance in the good to very good range, with a class average of $82.40 \%$ for mathematics and $86.20 \%$ for science. Table 5 and Table 6 detail external results from national standardized tests for the academic year, with students scoring significantly higher in mathematics and science in not only the national level but in other groupings as well, indicating the positive effect of coaching on student achievement as measured by both internal and external evaluations.

Table 2. The mean standard deviation of student satisfaction of science teacher performance.

\begin{tabular}{|c|c|c|c|c|c|}
\hline \multicolumn{3}{|c|}{ Competency by instructional area (science teacher) } & \multirow{2}{*}{$\begin{array}{c}\bar{x} \\
4.31\end{array}$} & \multirow{2}{*}{$\begin{array}{c}\text { Standard deviation (S.D.) } \\
\mathbf{0 . 7 2}\end{array}$} & \multirow{2}{*}{$\frac{\text { Degree of satisfaction }}{\text { High }}$} \\
\hline & uctional area 1: Knowledge and ability in subject & Combined average: & & & \\
\hline 1.1 & \multicolumn{2}{|c|}{ Introduces content to stimulate student interest } & 4.42 & 0.66 & High \\
\hline 1.2 & \multicolumn{2}{|l|}{ Is knowledgeable in content } & 4.21 & 0.69 & High \\
\hline 1.3 & \multicolumn{2}{|c|}{ Teaches content at appropriate level for students } & 4.20 & 0.84 & High \\
\hline 1.4 & \multicolumn{2}{|c|}{ Has clarity in teaching and explicit objectives } & 4.35 & 0.70 & High \\
\hline 1.5 & \multicolumn{2}{|c|}{ Has teaching activities that motivate self-learning } & 4.35 & 0.73 & High \\
\hline 1.6 & \multicolumn{2}{|c|}{ Provides various learning activities } & 4.21 & 0.84 & High \\
\hline 1.7 & \multicolumn{2}{|c|}{ Utilizes engaging teaching methods } & 4.30 & 0.55 & High \\
\hline 1.8 & \multicolumn{2}{|c|}{ Transfers knowledge and facilitates student understanding } & 4.38 & 0.63 & High \\
\hline 1.9 & \multicolumn{2}{|c|}{ Motivates and supports students to reach full potential } & 4.50 & 0.88 & Highest \\
\hline 1.10 & \multicolumn{2}{|c|}{ Creates and maintains environment conducive to learning } & 4.26 & 0.93 & High \\
\hline 1.11 & \multicolumn{2}{|c|}{ Summarizes content with clear conclusion at end of each lesson } & 4.23 & 0.48 & High \\
\hline & Instructional area 2: Use of materials & Combined average: & 4.37 & 0.71 & High \\
\hline 2.1 & \multicolumn{2}{|c|}{ Uses materials and supplements to support teaching } & 4.42 & 0.66 & High \\
\hline 2.2 & \multicolumn{2}{|c|}{ Uses materials and supplements that encourage and facilitate learning } & 4.40 & 0.77 & High \\
\hline 2.3 & \multicolumn{2}{|c|}{ Has materials consistent with content } & 4.21 & 0.72 & High \\
\hline 2.4 & \multicolumn{2}{|c|}{ Makes use of supplemental documents and resources beyond class materials } & 4.45 & 0.70 & High \\
\hline & Instructional area 3: Evaluation & Combined average: & 4.35 & 0.71 & High \\
\hline 3.1 & Has tools and methods of evaluation & Combined average: & 4.23 & 0.75 & High \\
\hline 3.1 .1 & \multicolumn{2}{|l|}{ Hands-on experience/lab } & 4.21 & 0.84 & High \\
\hline 3.1 .2 & \multicolumn{2}{|l|}{ Worksheets and written exercises } & 4.23 & 0.48 & High \\
\hline 3.1 .3 & \multicolumn{2}{|l|}{ Examinations } & 4.26 & 0.93 & High \\
\hline 3.2 & Measures achievement by unit studied & Combined average: & 4.37 & 0.71 & High \\
\hline 3.2 .1 & \multicolumn{2}{|l|}{ Learning unit 1 : food \& nutrition } & 4.30 & 0.71 & High \\
\hline 3.2 .2 & \multicolumn{2}{|l|}{ Learning unit 2: the human body } & 4.42 & 0.53 & High \\
\hline 3.2 .3 & \multicolumn{2}{|c|}{ Learning unit 3: living and nonliving things } & 4.38 & 0.88 & High \\
\hline 3.2 .4 & \multicolumn{2}{|c|}{ Learning unit 4 : substances in everyday life } & 4.38 & 0.70 & High \\
\hline 3.3 & \multicolumn{2}{|c|}{ Openly discloses results from evaluations } & 4.35 & 0.50 & High \\
\hline 3.4 & \multicolumn{2}{|c|}{ Provides feedback to allow for self-improvement } & 4.40 & 0.72 & High \\
\hline 3.5 & \multicolumn{2}{|c|}{ Evaluates transparently, clearly and fairly } & 4.42 & 0.86 & High \\
\hline
\end{tabular}


Table 3. Internal primary 6 mathematics test results by units studied during coaching.

\begin{tabular}{lccc}
\hline \multicolumn{1}{c}{ Unit } & $\begin{array}{c}\text { Goal } \\
\text { target percentage }\end{array}$ & $\begin{array}{c}\text { Result } \\
\text { actual percentage }\end{array}$ & $\begin{array}{c}\text { Difference of } \\
\text { result from goal }\end{array}$ \\
\hline $\begin{array}{l}\text { 1) Whole numbers (counting, addition, } \\
\text { subtraction, multiplication \& division) }\end{array}$ & 70 & 85.32 & +15.32 \\
2) Equations & 70 & 85.00 & +15.00 \\
3) Factors & 70 & 84.48 & +14.48 \\
4) Lines \& angles & 70 & 87.84 & +17.84 \\
5) Directions \& diagrams & 70 & 90.80 & +20.80 \\
6) Fractions (addition, subtraction, & 70 & 82.88 & +12.88 \\
multiplication \& division) & 70 & 86.05 & +16.05 \\
\hline \multicolumn{1}{c}{ Average } & & & \\
\hline
\end{tabular}

Table 4. Internal primary 6 science test results by units studied during coaching.

\begin{tabular}{lccc}
\hline \multicolumn{1}{c}{ Unit } & $\begin{array}{c}\text { Goal } \\
\text { target percentage }\end{array}$ & $\begin{array}{c}\text { Result } \\
\text { actual percentage }\end{array}$ & $\begin{array}{c}\text { Difference of } \\
\text { result from goal }\end{array}$ \\
\hline 1) Food \& nutrition & 70 & 84.24 & +14.24 \\
2) The human body & 70 & 83.84 & +13.84 \\
3) Living and nonliving things & 70 & 85.32 & +15.32 \\
4) Substances in everyday life & 70 & 84.80 & +14.80 \\
\multicolumn{1}{c}{ Average } & 70 & 84.55 & +14.55 \\
\hline
\end{tabular}

Table 5. 2015-2016 academic year primary 6 national standardized test results for mathematics.

\begin{tabular}{cccc}
\hline Level & Participants & Mean score & S.D. \\
\hline School (Bangpleepattanasuksalai) & 30 & 65.67 & 16.54 \\
School size & 235,225 & 40.77 & 18.84 \\
School location & 7924 & 43.94 & 19.35 \\
Province & 14,405 & 45.77 & 20.09 \\
Region & 152,559 & 44.51 & 20.01 \\
Country & 716,684 & 43.47 & 20.11 \\
\hline
\end{tabular}

Table 6. 2015-2016 academic year primary 6 national standardized test results for science.

\begin{tabular}{cccc}
\hline Level & Participants & Mean score & S.D. \\
\hline School (Bangpleepattanasuksalai) & 30 & 61.40 & 15.59 \\
School size & 235,253 & 41.15 & 12.69 \\
School location & 7925 & 42.97 & 12.88 \\
Province & 14,408 & 43.82 & 13.07 \\
Region & 152,573 & 43.14 & 13.10 \\
Country & 716,778 & 42.59 & 13.18 \\
\hline
\end{tabular}


On the part of the coaches, they found it helpful that the coachees were well indoctrinated by the management beforehand and were not opposed to being coached. The coaches discovered that the coachees already had innate skills but lacked experience to apply them correctly. Therefore, the coaches saw the need to teach the coachees how to successfully convey knowledge for the purpose of motivating students to participate and giving them the confidence to express opinions and present ideas, which are surefire indications of actual student comprehension and mastery of content.

\section{Conclusion}

Coaching systems can improve teachers' competencies and increase their efficacy but need clear aims and structure in order to succeed. It is management's responsibility to plan and steer the entire process and to ensure that stakeholders have adequate understanding and support as well as recognize its value (Matsumura, Sartoris, Bickel, \& Garnier, 2009).

Thailand yet lacks sufficient precedent in terms of teacher professional development by way of coaching and as such the pool from which to draw qualified coaches is still small. Coachee interest exists for more coaching, but the low number of eligible coaches limits the possibilities for matching coachees with coaches who are expert in different areas.

The heavy workloads and time constraints faced by Thai teachers, especially in private institutions, are significant obstacles and the problem is exacerbated if the coach's time is limited as well. The mathematics coachee noted that that her coach's inability to be more present on-site was a handicap. She believed increased interaction in person would have allowed for more dialogue, giving her more opportunity to offer her own input.

Implementing coaching systems across education in a broader scale has great potential to yield positive impacts, as they offer a sustainable process to improve and maintain standards. However, the above issues will need to be addressed if coaching is to be expanded systemically across the educational spectrum, and more examples of coaching systems for teachers beyond the limitations of this research need to be implemented in Thailand for further study because, if properly designed, executed and managed, coaching can improve the quality of the country's education by making excellent the vehicle that delivers it: teachers.

\section{Acknowledgements}

The author would like to express sincere gratitude to the following for their assistance and support: Associate Professor Dr. Malai Tawisook, King Mongkut's Institute of Technology Ladkrabang (advisor), Dr. Thanin Ratanaolarn, King Mongkut's Institute of Technology Ladkrabang (co-advisor), Associate Professor Prapon Chaicharoen, Srinakharinwirot University \& Prasarnmit Demonstration School (coaching consultant for mathematics), Associate Professor Atchara Chaicharoen, Srinakharinwirot University \& Prasarnmit Demonstration School 
(coaching consultant for science), Associate Professor Dr. Nataya Pilanthananond, Kasetsart University (content editor), and Mr. Nirut Chamsuwan, Bangpleepattanasuksalai School (consultant for English). Further thanks to all other associates and colleagues who were involved throughout the process of conducting this research.

\section{References}

Birman, B. F., Desimone, L., Porter, A. C., \& Garet, M. S. (2000). Designing Professional Development that Works. Educational Leadership, 57, 28-33.

Bruce, C. D., \& Ross, J. A. (2008). A Model for Increasing Reform Implementation and Teacher Efficacy: Teacher Peer Coaching in Grades 3 and 6 Mathematics. Canadian Journal of Education/Revue canadienne de l'éducation, 346-370.

Cantrell, S. C., \& Hughes, H. K. (2008). Teacher Efficacy and Content Literacy Implementation: An Exploration of the Effects of Extended Professional Development with Coaching. Journal of Literacy Research, 40, 95-127. https://doi.org/10.1080/10862960802070442

Cherkowski, S. (2012). Teacher Commitment in Sustainable Learning Communities: A New "Ancient" Story of Educational Leadership. Canadian Journal of Education, 35, 56-68.

Chien, C. W. (2013). Analysis of an Instructional Coach's Role as Elementary School Language Teachers' Professional Developer. Current Issues in Education, 16, 1-8.

Corcoran, T. (2015). Summary of Discourse on Improving Science Teaching. http://goo.gl/dIJVfw

Cornett, J., \& Knight, J. (2009). Research on Coaching. In Coaching: Approaches \& Perspectives (pp. 192-213). California: Corwin Press.

Darling-Hammond, L., Chung-Wei, R., \& Andree, A. (2010). How High Achieving Countries Develop Great Teachers. California: Stanford Center for Opportunity Policy in Education.

Garmston, R. (1987). How Administrators Support Peer Coaching. Educational Leadership, 44, 18-28.

Gallego Ortega, J. L., \& Fuentes, A. R. (2015). Communication Skills Training in Trainee Primary School Teachers in Spain. Journal of Teacher Education for Sustainability, 17, 86-98. https://doi.org/10.1515/jtes-2015-0007

Geng, G., Midford, R., \& Buckworth, J. (2015). Investigating the Stress Levels of Early Childhood, Primary and Secondary Pre-Service Teachers during Teaching Practicum. Journal of Teacher Education for Sustainability, 17, 35-47.

https://doi.org/10.1515/jtes-2015-0003

Iliško, D. (2007). Teachers as Agents of Societal Change. Journal of Teacher Education for Sustainability, 7, 14-26. https://doi.org/10.2478/v10099-009-0002-9

Joyce, B., \& Showers, B. (1982). The Coaching of Teaching. Educational Leadership, 40, 410.

Knight, J. (2007). Instructional Coaching: A Partnership Approach to Improving Instruction. Newbury Park, CA: Corwin Press.

Knight, J. (2009). Coaching. Journal of Staff Development, 30, 18-22.

Lieberman, A. (1995). Practices That Support Teacher Development: Transforming Conceptions of Professional Learning. In Innovating and Evaluating Science Education: 
NSF Evaluation Forums, $1992-94$ (p. 67).

Lord, P., Atkinson, M., \& Mitchell, H. (2008). Mentoring and Coaching for Professionals: A Study of the Research Evidence. Slough: National Foundation for Educational Research.

Matsumura, L. C., Sartoris, M., Bickel, D. D., \& Garnier, H. E. (2009). Leadership for Literacy Coaching: The Principal's Role in Launching a New Coaching Program. Educational Administration Quarterly, 45, 655-693.

https://doi.org/10.1177/0013161X09347341

Moffet, K. (1987). Training and Coaching Beginning Teachers: An Antidote to Reality Shock. Educational Leadership, 44, 34-37.

Robbins, P. (1991). How to Plan and Implement a Peer Coaching Program. http://goo.gl/msTZkS

Russo, A. (2004). School-Based Coaching. Harvard Education Letter, 20, 1-4.

Showers, B. (1985). Teachers Coaching Teachers. Educational Leadership, 42, 43-48.

Showers, B., \& Joyce, B. (1996). The Evolution of Peer Coaching. Educational Leadership, 53, 12-16.

Thailand Development Research Institute (2012). Much Learning, But Low Scores. http://goo.gl/oEy3Yz

Tilbury, D. (2007). Learning Based Change for Sustainability: Perspectives and Pathways. In A. E. J. Wals (Ed.), Social Learning towards a Sustainable World: Principles, Perspectives, and Praxis (pp. 117-131). Wageningen: Wageningen Academic Publishers.

Wenglingsky, H. (2000). How Teaching Matters: Bringing the Classroom back into Discussions of Teacher Quality. Princeton, NJ: Educational Testing Service.

Yoo, J. H. (2016). The Effect of Professional Development on Teacher Efficacy and Teachers' Self-Analysis of Their Efficacy Change. Journal of Teacher Education for Sustainability, 18, 84-94. https://doi.org/10.1515/jtes-2016-0007 